\title{
Proceeding
}

Supplementary Issue: Spring Conferences of Sports Science. Costa Blanca Sports Science Events, 19-20 June 2020. Alicante, Spain.

\section{Practical analysis of power in professional footballers}

\author{
YOFRE DANILO SANABRIA-ARGUELLO1 14 , CARLOS ALBERTO AGUDELO-VELASQUEZ², MAURO \\ CALLEJAS-CUERVO 3 \\ ${ }^{1}$ School of Physical Education, Pedagogical and Technological University of Colombia, Colombia \\ ${ }^{2}$ Antioquia University, Colombia \\ ${ }^{3}$ School of Computer Science, Software Research Group, Pedagogical and Technological University of \\ Colombia, Colombia
}

\begin{abstract}
The vertical jump measure the impulsive capacity, the main goal of this study is describing the coordination and elastic and contractile components of professional soccer players when performing the power test, through jumps, made on the Axom Jump 4.0 contact platform. It is an applicative study, since it carried out a jump test which provided inputs to define the training from the evaluated athletes must do. Sample population was 9 players who acted as midfielders average age: 22 years, size: 1,77: weight: $73 \mathrm{~kg}$ and BMI of 23.38, power was achieved through the Abalakov, SJ and CMJ jumps. The coordination and elastic influence was determined and correlated with BMl and compared with the other national and international populations. The IMB SPPS Statistics version 24 program was considered for the statistics. The assumption of normality was verified by applying the Shapiro-Wilk test and the correlation and differences with the parametric statistics were established. The power obtained was from 848,4 in the ABK, 845,0 $w$ in the squat jump and $844,2 \mathrm{w}$ in CMJ, which represents acceptable values against an international parameter. The jump valuation is related to the IE of the muscle fibres from the lower bod, and the CB which indicates the coordinative capacity of the players, the relationship of these determine the contribution of the muscle fibres, in this type of case the 9 evaluated players present very high values of muscular work or IC.

Keywords: Power; Skip ability; Power components; Individual tasks; Trainability; Sports performance.

\section{Cite this article as:}

Sanabria-Arguello, Y.D., Agudelo-Velasquez, C.A., \& Callejas-Cuervo, M. (2020). Practical analysis of power in professional footballers. Journal of Human Sport and Exercise, 15(3proc), S763-S769. doi:https://doi.org/10.14198/jhse.2020.15.Proc3.26

Corresponding author. School of Physical Education, Pedagogical and Technological University of Colombia, Colombia. https://orcid.org/0000-0003-2224-8261

E-mail: yofre.sanabria@uptc.edu.co

Supplementary Issue: Spring Conferences of Sports Science. Costa Blanca Sports Science Events, 19-20 June 2020. Alicante, Spain.

JOURNAL OF HUMAN SPORT \& EXERCISE ISSN 1988-5202

(C) Faculty of Education. University of Alicante

doi:10.14198/jhse.2020.15.Proc3.26
\end{abstract}




\section{INTRODUCTION}

There are several suggestions in order to achieve an optimal physical preparation (FP) in soccer players. These suggestions -among others-are the result of research: implementing and combining actions that involve maximum intensity with linear movements and changes of direction (Sánchez et al., 2016); including works with jumps (Loturco. et al., 2019); developing explosive strength and speed in young soccer players, since they present a correlation (Frazilli, De Arruda, Mariano \& Cossio, 2011); base their physical preparation more on own play actions in both soccer and futsal (Calle, Gutiérrez \& García, 2019); and to Including strength programs in young soccer players since positive effects are achieved (Sánchez-Sánchez et al., 2015).

To implement a physical preparation, it is important to understand the differences between professional soccer players and those in training ages, both in their anthropometric parameters and in the manifestations of strength and speed (Casais, Crespo, Domínguez \& Lago, 2004). This can generate that the positive effects are difficult (González-Millán et al., 2014) since they report that the saltability was not improved with an 11week strength program that did improve other variables in professional soccer players, which speaks of important levels of saltability in professional players. In the same page, no high correlations were found between maximum strength and anaerobic power tests in Argentine soccer players aged 18-20 years (Zubeldía \& Cocere, 2003).

In addition to the suggestion of including jumps as a working method, the use of jumps such as CMJ (countermovement jump) and SJ (vertical jump) is recommended for the measurement or valuation of power in several studies: Calahorro et al. (2011) present eight (8) studies in which different interventions between 6 and 16 weeks improved SJ between 2 and 31\% and CMJ between 2 and $24.5 \%$; the vertical jump as an indicator of the reactive strength in professional soccer players (Mariño, Becerra \& Bugallo, 2012); after 12 weeks of strength work to check the progress of 14-20 year old players (Méndez, Márquez \& Castro, 2007); to support improvements in strength using as training an isoinertial system. (Romero et al., 2014); effects of jump-based programs (Raya-González et al., 2016); with youth soccer players to verify improvements in strength with optimal weights in 8 weeks (Hernández \& Garcia. 2015); and it is even credited with the possibility that with the knowledge of its normative values explosive strength training can be properly prescribed in elite soccer players (Castagna \& Castellini. 2013).

Since basic movement patterns in soccer require a high development of rapid strength and power, in addition to the ability to efficiently use the stretch-shortening cycle in ballistic movements (García, Ruiz \& Latorre, 2015), measuring power with jumping is therefore very important and that is why this study aims to obtain such values in professional players of a Colombian soccer team, in order to be able to make practical recommendations about their FP.

The sample population presented the following average characteristics: age of 22.7 years, weight: $76.9 \mathrm{Kg}$ and height: $1.77 \mathrm{~cm}$., Power: $845 \mathrm{w}$., They have a minimum professional experience of five (5) years. The information was analysed with the SPSS 24 program, showing insignificant correlations between the power variables associated with the jumps and the BMI of the soccer players, in addition to a contractile index (Cl) and contribution of the arms (CB), which allows us to propose a reform in the training methodology. 


\section{MATERIALS AND METHODS}

The sample population consisted of $(n=9)$ professional soccer players, such sample was at the convenience of the researchers, these athletes (midfielders) participated in the study voluntarily. A protocol based on three jumps was applied: a) the CMJ, which consists of performing a concentric contraction preceded by an eccentric one which could generate higher levels of force than an isolated concentric contraction, b) the SJ is a jump without counter movement (starting from a position $90^{\circ}$ flexion of the knee joint) allowing the explosive force of the lower limbs and c) the ABK, which is a jump with the help of the action of the arms, to be assessed by means of the height reached, each athlete made three attempts for each of the mentioned jumps, with an interval between 1 minute per attempt and 3 minute per jump. The jump evaluation was carried out on an Axon jump 4.0 contact platform. From each of the jumps, the average jump height is obtained and the statistics were analysed with the SPSS 24 program.

The Body Mass Index (BMI) was determined by means of the Quetelet index, the elastic index was evaluated based on the difference between the SJ and the CMJ jump; as well as lower limb muscle power using the Harman formula (Harman et al., 1991).

\section{RESULTS}

In the Table 1 is shown the jumping results of the 9 evaluated midfielders.

Table 1. Power and height reached.

\begin{tabular}{lllllllllllll}
\hline ID & Weight & Size & IMC & $\begin{array}{l}\text { ABK } \\
\text { Height } \\
(\mathbf{m})\end{array}$ & $\begin{array}{l}\text { SJ } \\
\text { Height } \\
(\mathbf{m})\end{array}$ & $\begin{array}{l}\text { CMJ } \\
\text { Height } \\
(\mathbf{m})\end{array}$ & $\begin{array}{l}\text { ABK } \\
\text { Power }\end{array}$ & $\begin{array}{l}\text { SJ } \\
\text { Power }\end{array}$ & $\begin{array}{l}\text { CMJ } \\
\text { Power }\end{array}$ & IE\% & CB\% & IC\% \\
\hline 1 & 78 & 1.79 & 24.34 & 0.473 & 0.407 & 0.407 & 1015.3 & 1011.2 & 1011.2 & 0.0 & 16.2 & 83.8 \\
2 & 73.4 & 1.83 & 21.91 & 0.441 & 0.392 & 0.389 & 847.7 & 844.7 & 844.5 & 0.9 & 13.5 & 85.6 \\
3 & 72.5 & 1.77 & 23.14 & 0.485 & 0.475 & 0.415 & 818.0 & 817.4 & 813.7 & -13 & 17 & 96 \\
4 & 81 & 1.87 & 23.16 & 0.445 & 0.378 & 0.374 & 1121.5 & 1117.4 & 1117.2 & 1.0 & 19.0 & 80.0 \\
5 & 69.5 & 1.71 & 23.77 & 0.550 & 0.481 & 0.502 & 714.0 & 709.8 & 711.1 & -4.4 & 9.4 & 94.9 \\
6 & 74 & 1.78 & 23.36 & 0.524 & 0.453 & 0.429 & 874.4 & 870.0 & 868.6 & 5.3 & 22.1 & 72.6 \\
7 & 71.7 & 1.75 & 23.41 & 0.521 & 0.441 & 0.441 & 791.4 & 786.5 & 786.5 & -0.1 & 18.1 & 82.0 \\
8 & 73 & 1.75 & 23.84 & 0.461 & 0.389 & 0.378 & 834.5 & 830.1 & 829.4 & 2.8 & 22.1 & 75.1 \\
9 & 67 & 1.69 & 23.46 & 0.473 & 0.457 & 0.422 & 619.3 & 618.3 & 616.1 & 7.7 & 12.3 & 80.0 \\
\hline
\end{tabular}

Table 2. Normality of variables.

\begin{tabular}{lc}
\hline Variable & Shapiro-Wilk \\
\hline Weight in Kg & .755 \\
Size in m & .923 \\
IMC & .240 \\
Height in ABK & .430 \\
Height in SJ & .283 \\
Height in CMJ & .276 \\
power ABK & .758 \\
Power SJ & .750 \\
Power CMJ & .749 \\
Elastic Index & .236
\end{tabular}


\begin{tabular}{ll}
\hline Arms contribution & .754
\end{tabular}

Contractile Index $\quad .451$

The values obtained in Table 2 indicate that all the variables evaluated comply with the Normality assumption, therefore, the description of variables is made with the mean and standard deviation (Table 3) and the correlation of BMl with the variables of jump, power and indices is done through the Pearson Correlation. (Table 4).

Table 3. Descriptive Statistics of the variables evaluated.

\begin{tabular}{lcccc}
\hline Variable & Minimum & Maximum & Medium & Standard Deviation \\
\hline Weight in Kg & 67.0 & 81.0 & 73.344 & 41.726 \\
Size in m & 1.69 & 1.87 & 17.711 & 0.05578 \\
IMC & 21.91 & 24.34 & 233.767 & 0.66706 \\
Height in ABK & 0.441 & 0.550 & 0.48589 & 0.037807 \\
Height in SJ & 0.378 & 0.481 & 0.43033 & 0.039310 \\
Height in CMJ & 0.374 & 0.502 & 0.41744 & 0.039093 \\
power ABK & 619.3 & 1121.5 & 848.456 & 1.491 .778 \\
Power SJ & 618.3 & 1117.4 & 845.044 & 1.485 .460 \\
Power CMJ & 616.1 & 1117.2 & 844.256 & 1.488 .444 \\
Elastic Index (IE) & -13.0 & 7.7 & 0.022 & 59.728 \\
Arms contribution (CB) & 9.4 & 22.1 & 16.633 & 43.122 \\
Contractile Index (IC) & 72.6 & 96.0 & 83.333 & 79.575 \\
\hline
\end{tabular}

Table 4. Correlations between power variables and BMC.

\begin{tabular}{lccccccccc}
\hline $\begin{array}{l}\text { Correlation } \\
\text { with the IMC }\end{array}$ & $\begin{array}{c}\text { Height } \\
\text { in ABK }\end{array}$ & $\begin{array}{l}\text { Height } \\
\text { in SJ }\end{array}$ & $\begin{array}{l}\text { Height } \\
\text { in CMJ }\end{array}$ & $\begin{array}{l}\text { Power } \\
\text { in ABK }\end{array}$ & $\begin{array}{l}\text { Power } \\
\text { in SJ }\end{array}$ & $\begin{array}{c}\text { Power } \\
\text { in CMJ }\end{array}$ & IE & CB & IC \\
\hline Correlation & .375 & .179 & .276 & .037 & .034 & .035 & .052 & .124 & -.107 \\
Significance & .320 & .645 & .472 & .926 & .931 & .928 & .894 & .750 & .783 \\
\hline
\end{tabular}

There are no highly significant correlations between the BMI and the power variables of the evaluated players.

\section{DISCUSSION}

In general, the group of soccer players evaluated presented a low elastic index for the development of the vertical jump, due to the differences found both individually and in groups between the SJ and CMJ jumps, showing that for the specific case of the group, the SJ jump was the of greater height above the CMJ, while in the study carried out by (Mariño et al., 2012) the CMJ jump presented higher levels of height than the SJ.

Comparing the average values of the jumps with the values reported by sport (Chamorro et al., 2012) it is found that the a) CMJ jump is superior $35.05 \mathrm{~cm}$ against $41.7 \mathrm{~cm}$; b) ABK jump is $42.46 \mathrm{~cm}$ against $48.6 \mathrm{~cm}$ and c) SJ jump is $32.54 \mathrm{~cm}$ against $43 \mathrm{~cm}$. Bringing the attention on the fact that for the reference the CMJ jump is greater than the SJ, contrary to the evaluated team.

The study carried out by (Jaramillo \& Jaramillo, 2019) found deficiencies in the contribution of the arms in a group of footballers belonging to a professional club from another Colombian city without presenting similarity with what was found in this study where it was acceptable with $16.6 \%$ in average. 
Grande (2009) found that midfielders achieve the highest height in the CMJ jump of $40.37 \pm 6.43 \mathrm{~cm}$., Without being significant differences among field positions. In the present study, only midfielders with an average of $41.7 \mathrm{~cm}$ were evaluated. García, Ruiz \& Latorre, (2015) conclude that in adolescent soccer players the differences in physical preparation are not significant, although the CMJ jump is greater in forwards and then in midfielders. above other field positions. In another study, it is found that in young women soccer players there are no differences in their abilities by positions (González-De los Reyes, Fernández-Ortega \& Garavito. 2018); however, for this study carried out with players from a professional team they should have higher values, it is found: that with reference to the CMJ jump the group presented a skip of $41.7(\mathrm{~cm})$ being 1.33 $\mathrm{cm}$ above the results obtained in the Grande study (2009), but below the study carried out by Marek (2019) at $1.07 \mathrm{~cm}$.

The evaluated players are below the average in the CMJ and SJ jump to the evaluated lower divisions of another city in Colombia (Méndez, Márquez \& Castro, 2007) thus CMJ: $50.21 \mathrm{~cm}$ against $41.7 \mathrm{~cm}$ and SJ: 45.37 against $43 \mathrm{~cm}$, showing in this particular case that in the referred study the CMJ jump is superior to the SJ jump, which is precisely the aspect that casts doubt on the level of training of the athletes of the present study since their SJ jump $(43 \mathrm{~cm})$ on average is greater than the CMJ jump $(41.7 \mathrm{~cm})$; This finding is ratified by comparing it with the reported mean values for children, cadets and youth (Casais et al, 2004) for the SJ jump (26.96, 31.05 and 31.80) and the CMJ jump (36.36, 42.25 and 43.36).

\section{CONCLUSION}

The valuation of the vertical jump is directly related to the elastic index (IE) of the muscle fibres of the lower body, and the contribution of the arms (CB), which constitutes an indicator of the coordinative capacity of the players, the relationship of these components determine the contribution of the muscle fibres, in this case the 9 evaluated players present very high values of muscular work or contractility index $(\mathrm{Cl})$.

A change in methodology is recommended in the training of the evaluated players, given that the findings imply a poor development of the elastic and coordinative potential essential for performance in modern soccer.

The suggested proposal for fitness trainers is to include a series of strength work that especially involves the quadriceps as an important predictor of jumping ability in performance soccer players.

\section{CONFLICT OF INTEREST}

The authors declare no conflict of interest.

\section{REFERENCES}

Calahorro, F., Torres-Luque, G., Lara, A.J. \& Zagalaz, M.L. (2011). Parameters related to the competition's physical training. Journal of Sport and Health Research. 3(2), 113-128.

Calle, C.P., Gutiérrez, M. \& García, M. (2019). Estudio sobre le entrenamiento de la fuerza explosiva en deportistas de fútbol sala de categorías formativas. Olimpia $V(16), 56,34-47$.

Casais, L., Crespo, J.J., Domínguez, E. \& Lago, C. (2004). Relación entre parámetros antropométricos y manifestaciones de fuerza y velocidad en futbolistas en edad de formación. Congreso Universidad de Vigo. 
Castagna, C. \& Castellini, E. (2013). Vertical Jump Performance in Italian Male and Female National Team Soccer Players. Journal os Strnength and Conditioning Research, 27(4), 1156-1161. https://doi.org/10.1519/JSC.0b013e3182610999

Chamorro, R.P., González, M., Expósito, I., Sirvent, J. \& García. M. (2012). Valores del Test de Bosco en Función del Deporte.

Frazilli. E.H., De Arruda, M., Mariano, T. \& Cossio, M.A. (2011). Correlación entre fuerza explosiva y velocidad en jóvenes futbolistas. Biomecánica. 19 (1), 19-24.

García, F., Ruiz, A. \& Latorre, P. (2015). Influence of specific position in power and agility of Young soccer players. Retos (27), 58-61.

González-De Los Reyes, Y., Fernández-Ortega, J. \& Garavito-Peña, F. (2019). Características de fuerza y velocidad de ejecución en mujeres jóvenes futbolistas. Revista Internacional de Medicina y Ciencias de la Actividad Física y el Deporte V, 19 (73), 167-179. https://doi.org/10.15366/rimcafd2019.73.012

González-Millán, C., Del Coso. J., Abián-Vicén, J., López del Campo, R., Gutiérrez, D. \& Salinero, J. J. (2014). Cambios en la fuerza de miembros inferiores tras un mesociclo de pretemporada en futbolistas semiprofesionales. Retos V (26), 52-55.

Grande, I. (2009). Valoración de la Potencia de salto en jugadores Semi Profesionales de fútbol y comparación por puestos. Kronos V (8), 79-84.

Harman, E.A., Rosenstein, M.T., Frykman, P.N., Rosenstein, R.M. \& Kramer, W.J. (1991). Estimates of human power output from vertical jump. J Appl Sport Sci Res, 5, 116-120. https://doi.org/10.1519/00124278-199108000-00002

Hernández, Y.H. \& García, J.M. (2015). Efectos de un entrenamiento específico de potencia aplicado a futbolistas juveniles para la mejora de la potencia en el salto. RICCAFD, V (4), 1, 28-41.

Jaramillo. M.C. \& Jaramillo. M.M. (2019). Correlación del Índice de Masa Corporal. Índices de saltabilidad y potencia muscular de miembros inferiores en los jugadores de fútbol de salón pertenecientes al equipo Santander FSC. Trabajo de Grado. Universidad Santo Tomás.

Loturco, I., Pereira, L., Reis, V., Bishop, C., Zanetti, V., Alcaraz, P., Freitas, T. \& Mcguigan, M. (2019). Power training in elite Young soccer players: effects of using loads above or below the optimun power zone. Journal of Sport Sciences.1-7. https://doi.org/10.1080/02640414.2019.1651614

Marek Popowczak, Andrzej Rokita, Kamil Świerzko, Stefan Szczepan, Ryszard Michalski, Krzysztof Maćkała. (2019). Are Linear Speed and Jumping Ability Determinants of Change of Direction Movements in Young Male Soccer Players?. Journal of Sports Science and Medicine PMCID: PMC6370957.

Mariño, N., Becerra, H. \& Bugallo, E. (2012). Análisis del rendimiento en el salto vertical de un grupo de deportistas del fútbol profesional colombiano. Revista AF y Desarrollo Humano. V(1), 24-31.

Méndez, E., Márquez, J. \& Castro, C. (2007). El trabajo de fuerza en el desarrollo de la potencia en futbolistas de las divisiones menores de un equipo profesional de fútbol. Latreia. V (20). 127-143.

Raya, J., Suárez, L., Moreno, M., Ruiz, J. \& Sáez, E. (2017). Short-term physical performance effects of two different neuromuscular oriented training programs on U-17 elite soccer players. Ricyde $\mathrm{V}(13)$, 88-103. https://doi.org/10.5232/ricyde2017.04801

Romero, S., Feria, A., Sañudo, S. B., De Hoyo, M., \& Del Ojo, J. J. (2014). Efectos de entrenamiento de fuerza en sistema isoinercial sobre la mejora del CMJ en jóvenes futbolistas de elite. Retos, (26).

Sánchez, J., Hernández, C., Muñoz, V., González, A. \& Carretero, M. (2016). Mejora de la capacidad para repetir sprint en jóvenes futbolistas: entrenamiento intermitente de alta intensidad con y sin cambios de dirección. Retos, 30, 70-75. 
Sánchez-Sánchez, J., Pérez, S., Yagüe, J.M., Royo, J.M. \& Martín, J.L. (2015). Aplicación de un programa de entrenamiento de fuerza en futbolistas. Revista Internacional de Medicina y Ciencias de la Actividad Física y el Deporte V. 15 (57), 45-59. https://doi.org/10.15366/rimcafd2015.57.004

Zubeldía, G. \& Coceres, H. (2003). Fuerza máxima y su relación con la potencia aeróbica en futbolistas de 18 a 20 años pertenecientes a Racing Club. G-SE, 1-11. 